\title{
Climate change impacts on Australia's alpine ecosystems
}

\author{
RACHEL SLATYER
}

\section{Abstract}

Global ambient temperatures have increased significantly (average $0.7^{\circ} \mathrm{C}$ ) over the last century. In high-altitude areas, concurrent changes in precipitation regimes are already having a noticeable impact on snow area, depth and persistence in alpine and subalpine zones. Australia's alpine habitat is limited, covering only approximately $0.15 \%$ of the continent. Changes in snow regimes predicted under future climate change are likely to have a significant impact on the animals and plants whose ecology is intrinsically linked to snow conditions. For small mammals, reduced snow depth and area will reduce the availability of suitable over-wintering habitat and could increase predation. However, these effects are species-specific. Changes in snow regimes are predicted to significantly alter the composition and distribution of alpine vegetation communities. In particular, movement of species ranges to higher altitudes is predicted to increase species diversity in the alpine zone (though with a likely loss of some species). Wildfires poses an additional threat to alpine plants and animals, with many species apparently vulnerable to an increase in fire frequency. However, they appear to be resilient to high wildfire intensity. Thus, while climate change presents a significant threat to Australia's alpine ecosystems, the specific impacts will depend on the resilience and adaptability of individual species.

\section{Introduction}

Current global climate change is likely to affect natural ecosystems worldwide. In Australia, average maximum and minimum temperatures have increased by $0.6^{\circ} \mathrm{C}$ and $1.2^{\circ} \mathrm{C}$ respectively over the last century (Hennessy et al. 2007). Furthermore, the rate of warming appears to be increasing globally (Hennessy 
et al. 2007; Trenberth 2007). Concurrent changes in precipitation and other environmental factors such as fire regimes are likely to have a significant impact on the diversity and distribution of species and ecosystems.

Mountain regions may be particularly affected by climate change: warming is thought to be occurring more rapidly in alpine areas than at lower elevations (Beniston et al. 1997, Diaz \& Bradley 1997) and species already occupying high-altitude areas have little scope for up-slope migration (Beniston 2003; Hennessy et al. 2003; Walther et al. 2005). Habitat loss and fragmentation under climate change are significant threats to these ecosystems, with the creation of progressively smaller 'islands' of alpine and subalpine habitat (see Figure 1), within a 'sea' of montane woodland.

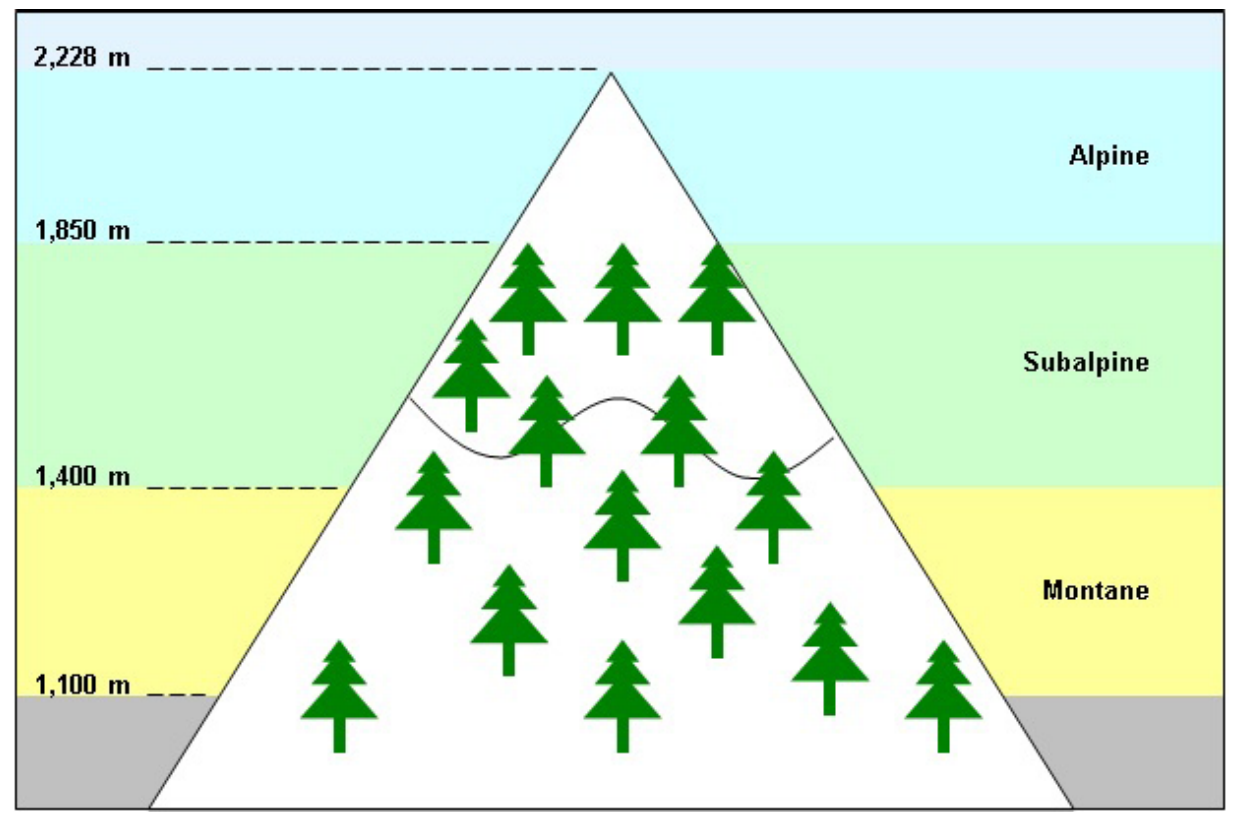

Figure 1. Diagram depicting mountain habitats. The alpine region comprises the alpine and subalpine zones, with the former extending above the tree line and the latter extending from the snow line to the tree line. The montane zone is woodland, below the snow line. Approximate elevations of the zone margins in the Mt. Kosciuszko alpine area in New South Wales are given.

Australia's alpine regions (Figure 2) cover only $0.15 \%$ of the continent, with an altitudinal range of just 400m (Costin 1957; Pickering and Armstrong 2003; Williams et al. 2008). On mainland Australia, the most extensive alpine areas occur in the Snowy Mountains of New South Wales, and the Bogong High Plains in Victoria (Williams et al. 2008). These areas have warmed by approximately 
$0.2^{\circ} \mathrm{C}$ over the last 35 years (Hennessy et al. 2003) and Australia's alpine zones have been identified as one of six key regions that are highly vulnerable to climate change (Hennessy et al. 2007).

This review summarises current trends and projected effects of climate change on Australia's alpine environments, with a focus on snow cover, and examines the predicted impacts of these environmental changes on alpine biodiversity.

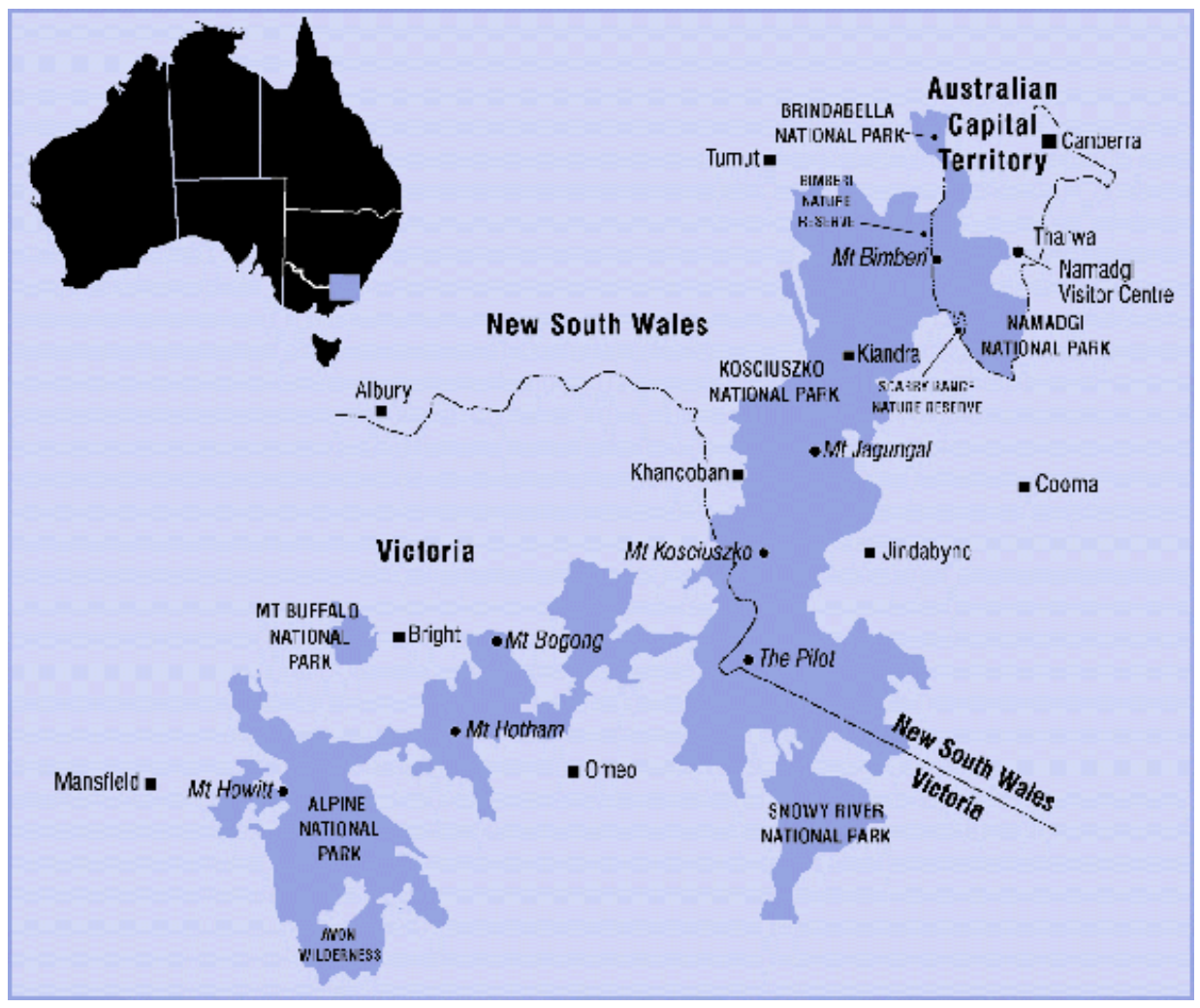

Figure 2. Map of Australia's mainland alpine areas in dark shading.

\section{Trends and predictions for snow cover in Australian alpine areas}

Perhaps the most immediate and important effect of climate change on alpine environments worldwide is its impact on snow cover. Climate change models predict a 0.5 to $1.5^{\circ} \mathrm{C}$ warming and up to $10 \%$ less precipitation (relative to 
1990) in southeastern Australia by 2030 (Suppiah et al. 2007). Corresponding models for alpine areas estimate a temperature rise of up to $1^{\circ} \mathrm{C}$ temperature and $8.3 \%$ less precipitation by 2020 (Table 1), both of which are likely to affect snow conditions (Hennessy et al. 2003). The distributions of many species are determined by snow - its presence or absence, depth and persistence (Green and Osborne 1998; Matthews 2010). Consequently, changes in snow conditions are likely to have a substantial impact on biodiversity in alpine regions.

Globally, average snow cover has decreased by $10 \%$ since the late 1960s (Matthews 2010; Walther et al. 2002). Climate models, incorporating high- and low-impact changes in temperature and precipitation, predict a decline in the area of snow cover in Australia of between 22 up to $85 \%$ by 2050 (Hennessy et al. 2003). This projected decline is accompanied by a trend for an upward shift in the snow line (Hennessy et al. 2003). On Mt. Kosciuszko, the snow line is predicted to rise from its current elevation of $1460 \mathrm{~m}$ to between $1490 \mathrm{~m}$ and $1625 \mathrm{~m}$ by 2020 (Hennessy et al. 2003), while more recent models project an overall rise of 60 to $570 \mathrm{~m}$ by 2050 (Hennessy et al. 2007). This represents a reduction in the altitudinal range of the alpine/subalpine zones of between $7 \%$ and $74 \%$.

In the Kosciuszko alpine area, maximum snow depth has decreased by approximately $10 \%$ and spring snow depth has declined by $40 \%$ over the last 40 years (Nicholls 2005). Climate models predict a further decrease in maximum snow depth of up to $99 \%$ (relative to 1990) by 2050 (Hennessy et al. 2007).

The Australian alpine zone typically has continuous snow cover for at least four months per year, with some snow patches persisting throughout the summer (Edmonds et al. 2006; Green and Pickering 2002). Green and Pickering (2009) estimate that snow thaw has occurred, on average, 2 days earlier per decade since 1954, with reduced variation in the date of first snow melt. A further decrease in snow persistence is predicted under both low- and high-impact climate change scenarios (Table 1; Hennessy et al. 2007). 
Table 1. Predicted changes in temperature, precipitation, snow cover area, snow line and snow persistence under low- and high-impact climate change scenarios for 2020 and 2050, relative to 1990.

\begin{tabular}{llllll}
\hline & $\begin{array}{l}\text { Temperature } \\
\left({ }^{\circ} \mathrm{C}\right)\end{array}$ & $\begin{array}{l}\text { Precipitation } \\
(\%)\end{array}$ & $\begin{array}{l}\text { Snow cover } \\
(\%)\end{array}$ & $\begin{array}{l}\text { Snow line } \\
\text { (at Mt. } \\
\text { Kosciuszko; m) }\end{array}$ & $\begin{array}{l}\text { Snow } \\
\text { persistence } \\
\text { (days) }\end{array}$ \\
\hline $\begin{array}{l}\text { Low impact } \\
2020\end{array}$ & +0.2 & +0.9 & -10 & +30 & -5 \\
$\begin{array}{l}\text { High impact } \\
2020\end{array}$ & +1.0 & -8.3 & -39 & +165 & -40 \\
$\begin{array}{l}\text { Low impact } \\
2050\end{array}$ & +0.6 & +2.3 & -22 & +60 & -15 \\
$\begin{array}{l}\text { High impact } \\
2050\end{array}$ & +2.9 & -24.0 & -85 & +570 & -100 \\
\hline
\end{tabular}

Derived from Hennessy et al. 2007 and Hennessy et al. 2003.

\section{Diversity in Australian alpine regions and impacts of climate change}

Snow is ecologically important for both animals and plants inhabiting alpine and subalpine zones worldwide (e.g. Matthews 2010; Stenseth et al. 2004; Wipf and Rixen 2010). Reduced snow cover, depth and persistence predicted under climate change are therefore likely to have significant impacts on the distribution and diversity of species in alpine environments.

\section{Alpine fauna}

Australia's alpine fauna are thought to be highly vulnerable to the effects of climate change (Hughes 2003). Four small mammal species are common in the mainland alpine region: the mountain pygmy-possum (Burramys parvus), bush rat (Rattus fuscipes), broad-toothed rat (Mustacomys fuscus), and dusky antechinus (Antechinus swainsonii) (Broome 2001). In winter, these animals rely on cavities in rocks and insulated space formed by heathland shrubs, underneath the snow pack (subnivean space) (Sanecki et al. 2006a; Sanecki et al. 2006b). Reduced snow cover (both in area and depth) will therefore impact directly on these species by reducing the availability of subnivean habitat. It may also increase their susceptibility to predation (Green and Sanecki 2006) and/or reduce their competitive advantage over low-altitude species (Table 2) (Green and Pickering 2002). 
The mountain pygmy-possum, Australia's only obligate alpine mammal, is considered to be particularly sensitive to climate change - models suggest a complete disappearance of its bioclimatic range with a $1^{\circ} \mathrm{C}$ rise in temperature accompanied by a $5 \%$ reduction in winter precipitation (Brereton et al. 1995). Adults hibernate under the snow for up to seven months of the year (Broome 2001). Winter snow cover is critically important for hibernation, as it dampens subnivean temperature fluctuations, so that individuals are usually exposed to temperatures between $1.5^{\circ} \mathrm{C}$ and $2.5^{\circ} \mathrm{C}$ (Kortner and Geiser 1998). In natural conditions, Kortner and Geiser (1998) found that bouts of hibernation were longest as the possum's body temperature approached $2^{\circ} \mathrm{C}$, while earlier laboratory experiments demonstrated that energy conservation was greatest when ambient temperature was also $2^{\circ} \mathrm{C}$ (Geiser and Broome 1993). Energy use increases eightfold when ambient temperature falls to $0^{\circ} \mathrm{C}$ and individuals lose almost four times more body mass per day than at $2^{\circ} \mathrm{C}$ (Geiser and Broome 1993). Shallower snow cover and an increased proportion of precipitation falling as rain rather than snow will cause greater temperature fluctuations. This, in turn, is likely to cause more frequent arousals, greater loss of stored body fat and higher winter mortality (Geiser and Broome 1993; Hennessy et al. 2003; Körtner and Geiser 1998). Over-winter survival in this species is already low (70\% for adult females, $40 \%$ for adult males) and declining population numbers in lowsnow years have previously been noted (Green and Pickering 2002).

Changes in snow conditions might also have an important impact on predation patterns, in addition to the direct affects on subnivean space. In contrast to mountain pygmy-possums, broad-toothed rats, bush rats and dusky antechinus are active under the snow during winter and vulnerable to predation (Green and Pickering 2002). Over three years, Green (2003) found that these species made up an average $86 \%$ of the diet of red foxes (Vulpes vulpes). In the alpine zone, spring diets in two of three years consisted entirely of these three mammals (Green 2003). The broad-toothed rat, listed as 'vulnerable' in New South Wales, is selectively targeted by foxes and constituted $45 \%$ to $82 \%$ of their diet (Green 2003). Broad-toothed rats cluster in subnivean nests during winter and substantial population declines in shallow-snow years have been attributed to increased fox predation (Green and Pickering 2002). Studies in North America have found increased predation of small mammals by foxes and coyotes when snow is shallow (Gese et al. 1996; Halpin and Bissonette 1988) as shallow snow is likely to minimise the effort required to dig up prey (Green and Pickering 2002; Halpine and Bissonette 1988). Selective predation on broad-toothed rats means that this species is the most vulnerable to climate change-induced increases in fox predation.

Predator-prey interactions will also be affected by changes in species' distributions and movement patterns. In Australia, the arrival times of at least 
seven bird species that migrate to alpine regions during spring have advanced by a month or more since the 1970s (reviewed: Chambers et al. 2005). Green (2010) examined the influence of temperature and thaw date on the arrival times of migratory birds and insects in the Kosciuszko alpine area over 30 years. He found that earlier snowmelt was associated with earlier arrival of Richards pipits (Anthus novaeseelandiae). In contrast, the alpine migration of bogong moths (Agrotis infusa), which form a key component of the spring and summer diets of many alpine birds (and mountain pygmy-possums), was not related to snow melt (Green 2010). These results suggest that advancement of the spring thaw could lead to an increasing mismatch between the timing of bird arrival and the availability of their major food source (Green 2010).

Climate change is expected to alter competitive interactions between species, so that some increase while others decline (Tylianakis et al. 2008). Altitudinal shifts in the distribution of Australian alpine animals, observed over the 30 years prior to 1999 , suggest that some species are already responding to general warming (Green and Pickering 2002). The broad-toothed rat, dusky antechinus and mountain pygmy-possum are the only Australian mammals whose abundance increases with altitude. This suggests that they may hold a competitive advantage over similar, lower-altitude species (swamp rat (Rattus lutreolus), agile antechinus (Antechinus agilis) and Eastern pygmy-possum (Cercartetus nanus) respectively) in alpine and subalpine zones (Green and Pickering 2002). Decreased snow cover could reduce these competitive advantages and allow expansion of species (both native and feral) whose distributions are currently restricted by snow cover (Green and Pickering 2002). For example, bioclimatic modelling suggests that there is potential for increased overlap in the distributions of swamp rats and broad-toothed rats with local warming (Green et al. 2008). However, a recent study by Matthews et al. (2010) showed that topography, soil, vegetation and local habitat features might constrain the distributions of animals, independent of snow cover. This means that nonclimatic factors could moderate (or exacerbate) the effects of climate change and increases the difficulty of accurately predicting future species' distributions. 
The ANU Undergraduate Research Journal Volume Two 2010

Table 2. Summary of the predicted effects of snow regime changes on Australian alpine fauna.

\begin{tabular}{llll}
\hline Species/group & $\begin{array}{l}\text { Predicted effect of } \\
\text { changes in snow regimes }\end{array}$ & Cause & Reference \\
\hline $\begin{array}{l}\text { Mountain } \\
\text { pygmy-possum }\end{array}$ & Range contraction & Reduced snow cover & Brereton et al. (1995) \\
& $\begin{array}{l}\text { Increased winter } \\
\text { mortality }\end{array}$ & Reduced snow depth & $\begin{array}{l}\text { Geiser \& Broome } \\
\text { (1993); Körtner }\end{array}$ \\
& & & \& Geiser (1998); \\
& & & Hennessy et al. \\
(2003)
\end{tabular}

\section{Alpine flora}

Alpine plant life is largely governed by temperature and the duration and depth of snow cover (Gonzalo-Turpin and Hazard 2009). The impacts of global warming on Australia's alpine plants are expected to vary considerably with vegetation type (summarised in Table 3). Climate change effects on alpine vegetation may also vary at different spatial scales. For example, Edmonds et al (2006) predicted an increase in species richness at a small scale as species immigrate from adjacent habitats. However, Good (1998) suggested that plant diversity would decrease across the alpine habitat as a whole, due to loss of species that are restricted to areas with persistent summer snow. The communities most at risk are snowpatch feldmark and short alpine herbfields, which are associated with late snowdrifts and dependent upon snowmelt water during summer (Good 1998; Pickering and Armstrong 2003; Scherrer and Pickering 2001).

Late summer snowdrifts represent an important aspect of the alpine environment that is likely to change under global warming, with models predicting a decrease in both their size and number (Edmonds et al. 2006). Persistent snowdrifts constrain the time available for plants to grow and reproduce, but also hydrate the soil and influence soil chemistry (Edmonds et al. 2006; Slatyer et al. 1984). 
In one large-scale study, areas with greater summer snowdrift persistence had a lower number and diversity of vascular plants (Edmonds et al. 2006). However, loss of this habitat under global warming is likely to result in diminution of plant species associated with persistent summer snow (Edmonds et al. 2006). Decline of a key snowpatch feldmark species, Coprosma niphophila, since surveys in the 1970s may be an early reflection of such changes (Edmonds et al. 2006; Pickering and Armstrong 2003).

In Victoria, forest trees, principally Eucalyptus pauciflora, are beginning to extend their range into subalpine grassland (Wearne and Morgan 2001). However, this particular study could not conclude whether range shifts were due directly to climate change influences (Wearne and Morgan 2001). A recent meta-analysis of treeline data from 166 sites worldwide found that treeline advancement had occurred at approximately half of the sites and was associated with greater winter warming (Harsh et al. 2009). Although treeline shifts are likely to be slow (new E. pauciflora have established only a maximum of five metres from the forest-grassland boundary), species with greater dispersal capacity, such as many introduced weeds, may rapidly expand their ranges upslope as snow cover decreases (Wearne and Morgan 2001). A rising treeline will lead to extensive fragmentation of previously contiguous, treeless alpine habitat, increasing the extinction risk for species (both plant and animal) remaining in these alpine 'islands' (Halloy and Mark 2003; Moen et al. 2004). However, some plant species might have the potential to adapt to changing environmental conditions. Recent studies have found considerable local adaptation and genetic structuring of alpine plant species occurring along altitudinal gradients (e.g. Byars et al. 2009; Gonzalo-Turpin and Hazard 2009; but see: Byars and Hoffmann 2009). Local altitudinal adaptation, combined with gene flow, will enhance the potential of plants to adapt to environmental change (Gonzalo-Turpin and Hazard 2009). Species might also respond to climate change via phenotypic plasticity (Byars and Hoffmann 2009). For example, Byars and Hoffmann (2009) found marked differences between the leaves of Craspedia lamicola from high and low elevations, but most of this variation was attributable to environmental, rather than genetic differences (Byars and Hoffmann 2009). 
The ANU Undergraduate Research Journal Volume Two 2010

Table 3. Alpine vegetation types and their predicted response to climate change.

\begin{tabular}{lll}
\hline Vegetation type/species & $\begin{array}{l}\text { Predicted response to climate } \\
\text { change }\end{array}$ & Reference \\
\hline Ranunculus niphophilus (herb) & Decline & Edmonds et al. (2006) \\
Cushion plants & Decline & Edmonds et al. (2006) \\
Rushes & Decline & Edmonds et al. (2006) \\
Fen and bog & Decline & Pickering and Armstrong \\
& & (2003) \\
Short alpine herbfield & Decline & Pickering and Armstrong \\
& & (2003); Scherrer and \\
Tall alpine herbfield & Pickering (2003) \\
Snowpatch feldmark & & Pickering and Armstrong \\
Windswept feldmark & Decline & (2003) \\
& & Pickering and Armstrong \\
Trees & Expansion & (2003) \\
Shrubs & & Pickering and Armstrong \\
Heath & Expansion & (2003) \\
\hline
\end{tabular}

\section{Fire in alpine regions}

Wildfires have played an integral role in shaping Australia's environment and biological diversity. Historically, large fires have occurred infrequently in alpine regions (reviewed: Williams et al. 2008), but climate models suggest that changes in temperature, precipitation, humidity and wind-speed in the future are likely to increase both the frequency and severity of wildfires in the future (Hennessy et al. 2005). In early 2003, wildfires burnt $70 \%$ of the alpine and subalpine zones of southeastern Australia, providing a unique opportunity to examine the responses of plants and animals to large-scale fires (Green 2006). Encouragingly, over $90 \%$ of plant species regenerated quickly and several species even appeared to be more abundant (or present where they had previously been absent) after the fire (Walsh and McDougall 2004; Williams et al. 2008). Thus, alpine vegetation was generally resilient to fire.

Extensive loss of heathland shrubs, which form the structural base of subnivean habitat, is thought to have led to significant declines of bush rat, broad-toothed rat and dusky antechinus populations in the winter following the fires (Green and Sanecki 2006; Williams et al. 2008). Slow regeneration of heath (5- 20 years) means that small mammals are likely to be susceptible to an increased fire 
frequency that does not allow adequate recovery of subnivean habitat (Bradstock 2008; Williams et al. 2008). Mountain pygmy-possums, whose boulderfield habitat provides additional subnivean space that is relatively resistant to fire, and corroboree frogs (Pseudophryne spp.), which occupy wet areas, were more resistant to fire effects (Williams et al. 2008). No population declines (and even a slight increase) were detected for the nationally vulnerable northern corroboree frogs at 34 sites in the Mt. Kosciuszko area (Williams et al. 2008).

\section{Future directions}

Species can respond to climate change by migration, adaptation or plastic changes and different species experiencing the same environmental changes are likely to show a range of responses (Byars and Hoffmann 2009). Migration potential is limited in the alps, but studies in plants indicate both plastic and adaptive responses to environmental gradients (e.g. Byars and Hoffmann 2009; Byars et al. 2009). The adaptive potential of alpine animals has not been thoroughly studied, but low dispersal and gene flow between populations (Koumoundouros et al. 2009; Mitrovski et al. 2007) is likely to limit rapid adaptation. Thus, phenoytpic plasticity is likely to be an important determinant of a species' resistance to climate change and this is a key area for future research. For example, one question might be: 'can small mammals change their behaviour to ameliorate the effects of reduced snow cover duration?'

Our understanding of the impact of climate change on ecosystems is far from complete, but obtaining accurate predictions of future environment scenarios is important for conservation management. Predictions arising from climate change models are typically at a broad scale, with much higher uncertainty for changes at a small scale. Localised cooling and drying over the last 20 years has been reported in southeastern Tasmania, contrasting with global warming trends (Kirkpatrick et al. 2002). Thus, local models for climate change are necessary if these are to be useful for species management. In addition, the high uncertainty inherent in many climate change models means that predictions arising from these models should be used with careful consideration of the assumptions included in the model. For example, Hennessy et al. (2007) predicted only a 7\% reduction in the alpine zone under the lowest-impact model. This change on its own would probably have minimal impact on the abundance or distribution of species. However, the high-impact model predicted a $74 \%$ loss of alpine zone habitat - clearly a concern for those species restricted to the alpine zone. Given this uncertainty, local models that provide shorter-term (and therefore more accurate) estimates will be more useful for predicting the impacts of climate change on biodiversity and for conducting research into species responses to climate change. 
A third area that should be a focus of future research is non-climatic factors that could moderate or exacerbate direct climate-change effects. For example, alpine species are predicted to lose their competitive advantage over lower-altitude species as snow cover decreases. This indirect threat of climate change is additional to the direct effects of reduced snow cover. However, if non-climatic factors can negate the indirect effects (e.g. if the distribution of low-altitude species are limited by factors other than snow cover), the alpine biota may be better able to withstand the direct impacts of climate change. Alternatively, climate change could exacerbate current threats to biodiversity, such as predation by introduced predators. Understanding the interactions between these direct and indirect effects of climate change is the next step towards being able to effectively predict and conserve biodiversity.

Finally, while this review has focussed on the impacts of changes in snow cover as a result of global climate change, other factors including ultraviolet radiation (which might particularly affect high altitude amphibians), wind patterns, and human activities might also change in the future, causing additional impacts on natural systems. Estimates of the changes likely to occur, and research into their potential effects are now necessary.

\section{Conclusions}

The Australian alpine region is a unique habitat that is threatened by current and future climate change. Some of Australia's alpine species appear to be under significant threat from direct and indirect effects of climate change impacts on snow cover. For example, the mountain pygmy-possum is likely to suffer from significant habitat loss, and increased fox predation threatens broad-toothed rat populations. Several plant species are also predicted to decline or disappear. Alpine species are generally resilient to fire, but an increased frequency of natural wildfires is likely to cause significant population declines. However, Australia's alpine environment and its biodiversity may be resistant to the effects of at least low-impact climate change.

\section{References:}

Beniston M., Diaz H.F., Bradley R.S. (1997) Climatic change at high-elevation sites: an overview. Climatic Change 36, 233-252

Beniston M. (2003) Climatic change in mountain regions: A review of possible impacts. Climatic Change 59, 5-31. 
Bradstock R. A. (2008) Effects of large fires on biodiversity in south-eastern Australia: disaster or template for diversity? International Journal of Wildland Fire 17, 809-22.

Brereton R., Bennet S. \& Mansergh I. (1995) Enhanced greenhouse climate change and its potential effect on selected fauna of south-eastern Australia: A trend analysis. Biological Conservation 72, 339-54.

Broome L. S. (2001) Density, home range, seasonal movements and habitat use of the mountain pygmy-possum Burramys parvus (Marsupialia: Burramyidae) at Mount Blue Cow, Kosciuszko National Park. Austral Ecology 26, 275-92.

Byars S. G. \& Hoffmann A. A. (2009) Lack of strong local adaptation in the forb Craspedia lamicola in Southeastern Australia. International Journal of Plant Sciences 170, 906-17.

Byars S. G., Parsons Y. \& Hoffmann A. A. (2009) Effect of altitude on the genetic structure of an Alpine grass, Poa hiemata. Annals of Botany 110, 885-99.

Chambers L. E., Hughes L. \& Weston M. A. (2005) Climate change and its impact on Australia's avifauna. Emu 105, 1-20.

Costin A. B. (1957) The High Mountain Vegetation of Australia. Australian Journal of Botany 5, 173-89.

Diaz, H.F. \& Bradley, R.S. (1997) Temperature variations during the last century at high-elevation sites. Climatic Change 36, 253-279

Edmonds T., Lunt I. D., Roshier D. A. \& Louis J. (2006) Annual variation in the distribution of summer snowdrifts in the Kosciuszko alpine area, Australia, and its effect on the composition and structure of alpine vegetation. Austral Ecology 31, 837-48.

Geiser F. \& Broome L. S. (1993) The effect of temperature on the pattern of torpor in a marsupial hibernator. Journal of Comparative Physiology B 163, 133-7.

Gese E. M., Ruff R. L. \& Crabtree R. L. (1996) Intrinsic and extrinsic factors influencing coyote predation of small mammals in Yellowstone National Park. Canadian Journal of Zoology 74, 784-97.

Gonzalo-Turpin H. \& Hazard L. (2009) Local adaptation occurs along altitudinal gradient despite the existence of gene flow in the alpine plant species Festuca eskia. Journal of Ecology 97, 742-51.

Good R. (1998) Changing snow regimes and the distribution of alpine vegetation. In: Snow, a Natural History; an Uncertain Future (ed K. Green) pp. 98-112. Surrey Beatty \& Sons Pty Ltd Sydney. 
Green K. (2003) Altitudinal and temporal differences in the food of foxes (Vulpes vulpes) at alpine and subalpine altitudes in the Snowy Mountains. Wildlife Research 30, 245-53.

Green K. (2010) Alpine taxa exhibit differing responses to climate warming in the Snowy Mountains of Australia. Journal of Mountain Science 7, 167-75.

Green K. \& Osborne W. S. (1998) Snow as a defining character of the alpine/ subalpine fauna. In: Snow, a Natural History; an Uncertain Future (ed K. Green) pp. 141-64. Australian Alps Liaison Committee, Canberra.

Green K. \& Pickering C. (2002) A Scenario for Mammal and Bird Diversity in the Snowy Mountains of Australia in Relation to Climate Change. In: Mountain Biodversity: A Global Assessment (eds C. Körner and E. M. Spehn) pp. 23947. Parthenon Publishing Group, New York.

Green K. \& Sanecki G. M. (2006) Immediate and short-term responses of bird and mammal assemblages to a subalpine wildfire in the Snowy Mountains, Australia. Austral Ecology 31, 673-81.

Green K., Stein J. A. \& Driessen M. M. (2008) The projected distributions of Mastacomys fuscus and Rattus lutreolus in south-eastern Australia under a scenario of climate change: potential for increased competition? Wildlife Research 35, 113-9.

Halloy S. R. P. \& Mark A. F. (2003) Climate-Change Effects on Alpine Plant Biodiversity: A New Zealand Perspective on Quantifying the Threat. Arctic, Antarctic, and Alpine Research 35, 248-54.

Halpin M. A. \& Bissonette J. A. (1988) Influence of snow depth on prey availability and habitat use by red fox. Canadian Journal of Zoology 66, 58792.

Harsch M.A., Hulme P.E., McGlone M.S. \& Duncan R.P. (2009) Are treelines advancing? A global meta-analysis of treeline response to climate warming. Ecology Letters 12, 1040-1049

Hennessy K., Fitzharris B., B.C. Bates, Harvey N., Howden S. M., Hughes L., Salinger J. \& Warrick R. (2007) Australia and New Zealand. In: Climate Change 2007: Impacts, Adaptation and Vulnerability. Contribution of Working Group II to the Fourth Assessment Report of the Intergovernmental Panel on Climate Change (eds M. L. Parry, O. F. Canziani, J. P. Palutikof, P. J. v. d. Linden and C. E. Hanson) pp. 507-40. Cambridge University Press, Cambridge. 
Hennessy K., Lucas C., Nicholls N., Bathols J., Suppiah R. \& Ricketts J. (2005) Climate change impacts on fire-weather in south-east Australia. CSIRO Marine and Atmospheric Research, Aspendale, Victoria.

Hennessy K., Whetton P., Smith I., Bathols J., Hutchinson M. \& Sharples J. (2003) The impact of climate change on snow conditions in mainland Australia. CSIRO Atmospheric Research, Aspendale.

Hughes L. (2003) Climate change and Australia: Trends, projections and impacts. Austral Ecology 28, 423-443

Kirkpatrick J. B., Bridle K. L. \& Lynch A. J. J. (2002) Changes in alpine vegetation related to geomorphological processes and climatic change on Hill One, Southern Range, Tasmania, 1989-2000. Australian Journal of Botany 50, 7539.

Kortner G. \& Geiser F. (1998) Ecology of natural hibernation in the marsupial mountain pygmy-possum (Burramys parvus). Oecologia 113, 170-8.

Körtner G. \& Geiser F. (1998) Ecology of natural hibernation in the marsupial mountain pygmy-possum (Burramys parvus). Oecologia 113, 170-8.

Koumoundouros T., Sumner J., Clemann N. \& Stuard-Fox D. (2009) Current genetic isolation and fragmentation contrasts with historical connectivity in an alpine lizard (Cyclodomorphus praealtus) threatened by climate change. Biological Conservation 142, 992-1002.

Matthews A. (2010) Changes in fine-scale movement and foraging patterns of common wombats along a snow-depth gradient. Wildlife Research 37, 17582.

Matthews A., Spooner P. G., Lunney D., Green K. \& Klomp N. I. (2010) The influences of snow cover, vegetation and topography on the upper range limit of common wombats Vombatus ursinus in the subalpine zone, Australia. Diversity and Distributions 16, 277-87.

Mitrovski P., Heinze D. A., Broome L., Hoffmann A. A. \& Weeks A. R. (2007) High level of variation despite genetic fragmentation in populations of the endangered mountain pygmy-possum, Burramys parvus, in alpine Australia. Molecular Ecology 16, 75-87.

Moen J., Aune K., Edenius L. \& Angerbjoern A. (2004) Potential Effects of Climate Change on the Treeline Position in the Swedish Mountains. Ecology and Society 9, 16.

Nicholls N. (2005) Climate variability, climate change and the Australian snow season. Australian Meteorological Magazine 54, 177-85. 
Pickering C. M. \& Armstrong T. (2003) Potential impact of climate change on plant communities in the Kosciuszko alpine zone. Victorian Naturalist 120, $15-24$.

Sanecki G. M., Cowling A., Green K., Wood H. \& Lindenmayer D. (2006a) Winter distribution of small mammals in relation to snow cover in the subalpine zone, Australia. Journal of Zoology 269, 99-110.

Sanecki G. M., Green K., Wood H., Lindenmayer D. \& Sanecki K. L. (2006b) The influence of snow cover on home range and activity of the bush-rat (Rattus fuscipes) and the dusky antechinus (Antechinus swainsonii). Wildlife Research 33, 489-96.

Scherrer P. \& Pickering C. M. (2001) Effects of grazing, tourism and climate change on the alpine vegetation of Kosciuszko National Park. Victorian Naturalist 118, 93-9.

Slatyer R. O., Cochrane P. M. \& Galloway R. W. (1984) Duration and extent of snow cover in the Snowy Mountains and a comparison with Switzerland. Search 11-12, 327-31.

Stenseth N. C., Shabbar A., Chan K.-S., Boutin S., Rueness E. K., Ehrich D., Hurrell J. W., Lingjærde O. C. \& Jakobsen K. S. (2004) Snow conditions may create an invisible barrier for lynx. Proceedings of the National Academy of Sciences 101, 10632-4.

Suppiah R., Hennessy K. J., Whetton P. H., McInnes K., Macadam I., Bathols J., Ricketts J. \& Page C. N. (2007) Australian climate change projections derived from simulations performed for the IPCC 4th Assessment Report. Australian Meteorological Magazine 56, 131-52.

Trenberth K. E., Jones P. D., Ambenje P., Bojariu R., Easterling D., Klein Tank A., Parker D., Rahimzadeh R., Renwick J. A., Rusticucci M., Soden B. \& Zhai P., (2007) Observations: Surface and Atmospheric Climate Change. In: Climate Change 2007: The Physical Science Basis. Contribution of Working Group I to the Fourth Assessment Report of the Intergovernmental Panel on Climate Change (eds. Solomon, S., D. Qin, M. Manning, Z. Chen, M. Marquis, K.B. Averyt, M. Tignor and H.L. Miller). Cambridge University Press, Cambridge.

Tylianakis J.M., Didham R.K., Bascompte J. \& Wardle D.A. (2008) Global change and species interactions in terrestrial ecosystems. Ecology letters 11, 13511363

Walsh N. G. \& McDougall K. L. (2004) Progress in the recovery of the flora of treeless subalpine vegetation in Kosciuszko National Park after the 2003 fires. Cunninghamia 8, 439-52. 
Walther G.-R., Beissner S. \& Burga C. A. (2005) Trends in the upward shift of alpine plants. Journal of Vegetation Science 16, 541-8.

Walther G.-R., Post E., Convey P., Menzel A., Parmesan C., Beebee T. J. C., Fromentin J.-M., Hoegh-Guldberg O. \& Bairlein F. (2002) Ecological responses to recent climate change. Nature 416, 389-95.

Wearne L. J. \& Morgan J. W. (2001) Recent Forest Encroachment in Subalpine Grasslands near Mount Hotham, Victoria, Australia. Arctic, Antarctic, and Alpine Research 33, 369-77.

Wikimedia Commons (2010), Alpine regions of mainland Australia (not including Tasmania), http://en.wikipedia.org/wiki/File:AustAlpsRegionMap.png [Accessed 20 NOvember 2010].

Williams R. J., Wahren C. H., Tolsma A. D., Sanecki G. M., Papst W. A., Myers B. A., McDougall K. L., Heinze D. A. \& Creen K. (2008) Large fires in Australian alpine landscapes: their part in the historical fire regime and their impacts on alpine biodiversity. International Journal of Wildland Fire 17, 793-808.

Wipf S. \& Rixen C. (2010) A review of snow manipulation experiments in Arctic and alpine tundra ecosystems. Polar Research 29, 95-109. 